\title{
The changing nature of community service obligations in the postal sector and the future of Australia Post
}

\author{
Malcolm Abbott and Bruce Cohen ${ }^{1}$
}

\section{Abstract}

This article examines the theoretical bases for the existence of community service obligations (CSOs) in postal services in Australia. It assesses the forces that can be expected to affect both their form as well as the capacity of Australia Post to deliver CSOs into the future. It concludes by considering the implications of this assessment for Australia Post's ownership structure, strategic direction and its relationship with other communications, logistic and financial service providers, as well as with both the federal and state and territory governments.

\section{Introduction}

Australia Post ${ }^{2}$ is the oldest government business enterprise operating in Australia, although in recent years the nature of its business has changed dramatically. Traditional mail volumes have declined rapidly as technological change has enabled alternative means of communications, while parcel deliveries have increased as those same technologies have led to substantial growth in internet-based commerce.

\footnotetext{
Swinburne University of Technology, mabbott@swin.edu.au.

Australia Post refers to the Australian Postal Corporation, which is the government business enterprise established under the Australian Postal Corporation Act 1989 (Cth) (APC Act).
} 
Together with the role Australia Post now plays as a deliverer of retail, government and transaction services, there is a question for policymakers as to the efficacy of maintaining the postal-related community service obligations (CSOs) Australia Post has traditionally provided, whether those obligations should be reformed to meet more relevant current and future needs, and, relatedly, are those potential obligations best delivered by a government-owned entity such as Australia Post.

To this end, this article first considers the theoretical bases for the existence of CSOs in postal services. It then details the CSOs Australia Post currently delivers, before considering how changes in market conditions have altered both the need for such obligations and the financial capacity of Australia Post to deliver them. The article then goes on to assess the nature and extent of CSOs likely to be required in the future, and whether they are most appropriately provided by an entity such as Australia Post. The paper concludes by considering the implications of this assessment for Australia Post's ownership structure and strategic directionincluding its relationship with other communications, logistic and financial service providers, as well as with the federal and state and territory governments.

\section{CSOs in the postal sector: A brief background}

An important part of the justification for public ownership of Australia Post has been the CSOs that the organisation has been required to deliver. CSOs in the postal sector usually take the form of universal service obligations (USOs) (Australian Government Department of Communications, 2014). USOs are requirements imposed on service providers to provide a common minimum service offering to all potential customers, regardless of their location. Such obligations are common in a range of industries, including post, telecommunications and essential service utilities such as electricity and water supply.

CSOs in the form of USOs generally involve cross-subsidisation. Cross-subsidisation is the practice of charging prices to one type of consumers that are higher than that required to cover the costs associated with the service in question so as to artificially lower prices for another group. The formal definition of a cross-subsidy that has been developed in the economic literature comprises two tests that compare a service's revenues to different cost concepts. A service is a recipient of a crosssubsidy where revenue is less than the direct costs of providing the service. It also might be the beneficiary of a cross-subsidy where revenue is sufficient to cover the direct costs, but less than the sum of direct and attributable costs. In either case, the costs of providing the services is in part paid for from the revenue generated by a different service (Australian Competition and Consumer Commission, 2014, p. 1; Faulhaber, 1975, p. 966). 
Although public enterprises might cross-subsidise for political and equity reasons, it is also possible that they might do so for a variety of other objectives, such as to expand the scale of operations, perhaps because the managers of the enterprise benefit personally from expanded scale (Geddes, 1994; Niskanen, 1975; Sappington $\&$ Sidak, 2003). It is recognised in the literature that to cross-subsidise it is necessary to have a degree of market power in at least one market segment (Faulhaber, 1975, p. 972; Sidak, 2015, p. 617).

The USOs that operate in the postal sector are generally defined along three dimensions: product range, service quality and pricing constraints (e.g. affordability, uniform pricing) (Ambrosini et al., 2006; Gautier \& Poudou, 2014). In turn, service quality may encompass various aspects, including territorial coverage (ubiquity), transit time, accessibility of contact points and delivery frequency (Calzada, 2009). Thus, in the postal sector USOs generally take the form of uniform pricing structures for letters of a similar size and weight, as well as common delivery standards. These minimum service requirements are designed to ensure an affordable, reliable service is available to all members of the community. Without such USOs, the cost structures associated with the provision of the service would result in higher prices, lower standards and/or no services for customers located in areas characterised as more remote, less densely populated or less affluent. The application of uniform pricing for specified mail services is generally accompanied by regulatory imposed monopolies for these services - this approach aimed at underpinning the sustainability of the USOs by establishing exclusivity of service provision, which enables cross-subsidisation between profitable and non-profitable service areas (see Kenny, 2005). ${ }^{3}$

A range of reasons are posited for the imposition of USOs. A core justification is that the services provided by certain industries are essential to satisfy basic needs (Boldron et al., 2007). According to Boldron et al., this justification is founded on the notion of specific egalitarianism introduced by Tobin (1970):

that certain specific scarce commodities should be distributed less unequally than the ability to pay for them. Candidates for such sentiments include basic necessities of life, health, and citizenship. (p. 264)

Related to this notion, directed at meeting the needs of individuals who might otherwise suffer disadvantage, is the more collective-oriented justification that a uniform and universal postal network operates a binding force for communities, and as such has the characteristics of a 'public good' (Cremer et al., 1998, 2001; Jaag, 2013; Jaag \& Trinckner, 2011). In this regard, postal services have historically been integral in meeting the need of enabling the physical communications that underpin

3 Conversely, the capacity for USOs to be funded by a service provider is reduced where services are generally subject to competition, as this competition will manifest in those areas where profits are achievable (see Chone et al., 2000). 
and facilitate community and commercial activity, including the enforcement of property rights - both by establishing a consistent and legally accepted method by which members of the community can be located, as well as the means by which individuals, businesses and the state can communicate and, to varying degrees, transfer both documents and goods.

While such notions may be relied upon to support the direct or indirect provision of certain services as societal necessities, it does not provide a ready explanation for the form in which USOs have been imposed in the postal sector; that is, by way of regulated minimum standards. Relatedly, it does not provide an explanation as to why USOs in that form have traditionally applied to the provision of services such as post and telecommunications, but not for other basic needs such as, say, food or housing. Both the public economics and network economics literatures, however, provide potential explanations for the adoption of USOs in the form of minimum regulated standards, rather than relying on transfer payments and utilisation of market mechanisms to address issues of social disadvantage.

First, in the case of postal services, it is argued that the costs associated with identifying potential recipients for direct transfer payments to subsidise the costs of service may involve such time and expense as to make such an approach less efficient than simply imposing minimum standards, notwithstanding lowering costs overall may result in some overconsumption of services (see Jaag \& Trinckner, 2011).

Second, it is suggested that direct subsidies may not be the most efficient solution to meeting individual needs in the case of postal services because they are reliant on networks, which in turn give rise to network externalities (Boldron et al., 2009; Cremer et al., 1998, 2001). At its most fundamental level, postal services are a means for senders to overcome distances to recipients, acting as intermediaries that consolidate mail of different senders, thereby reducing transaction costs through the exploitation of scale, density and scope (Cuomo et al., 2013; Jaag \& Trinckner, 2011). As the postal service comprises a network enabling linkages between senders and recipients, expanding coverage can create economies of scale and scope that might not otherwise be achieved. This is because the private benefit to an individual customer may be insufficient to justify a decision on their part to partake in such a service, yet may be justified overall because others who are able to access the postal service enjoy a benefit from the increased coverage (Calzada, 2009; Jaag \& Trinckner, 2011; Willig, 1979). In this regard, the benefits of such expanded coverage are not confined to those who are recipients of postal services, but also extended to senders - for example, firms who have expanded potential customer bases than would otherwise be the case. As Boldron et al. (2009) note further, however, the utility of the network externalities are less likely to be as symmetric (i.e. as between senders and recipients) having regard to membership and usage in the postal sector than, say, in the telecommunications sector. Further, postal services networks are different from many other regulated networks in that they are more 
heavily dependent on human assets, as compared to other physical infrastructure: in particular, the people involved in the 'last mile' delivery aspects of the postal service (Meagli et al., 2011).

While these attributes provide economic justifications for USOs in the form of minimum standards, it should be recognised that such mechanisms may also reflect other, broader policy pressures - for example, a desire for governments to encourage particular regional development policies, which may be assisted by uniform pricing policies that represent a subsidy for individuals in particular locations. ${ }^{4}$ Relatedly, USOs of this nature may reflect a desire by governments to address political pressures from communities in such locations. The fact that such USOs are often provided by entities that are government-owned monopolies also facilitates requirements of this nature being instituted; as private sector providers in competitive markets would be less willing, or able, to meet such obligations internally. ${ }^{5}$ The following section details how the USOs that typically operate in the postal sector have manifested in Australia.

\section{CSOs and Australia Post}

Responsibility for the delivery of postal services sits with Australia Post, a publicly owned government business enterprise established and regulated under the Australian Postal Corporations Act 1989 (Cth) (APC Act) (as to the origins of postal services in Australia and the predecessor bodies of Australia Post, see Abbott, 2000, 2019). Pursuant to the APC Act (section 14), Australia Post's principal function is to supply postal services within Australia, and between Australia and overseas. In fulfilling this function, generally Australia Post has the exclusive right to carry certain letters within Australia, whether the letters originated within or outside Australia. The letters over which Australia Post has the exclusive right to deliver are defined on the basis of weight, size and thickness. The amount that Australia Post is able to charge for the delivery of such letters is subject to regulation and is capped. From 2016 until the end of 2019, the price of basic postage was set at $\$ 1.00$; this price having increased five times since 2000 (when the price was then 45 cents). This increase in prices in 2016 coincided with changes in delivery standards, which allowed longer time periods for the delivery for basic postal services (i.e. regular letters, as compared

\footnotetext{
4 Policy objectives may also militate against the imposition of USOs_-for example, environmental policies aimed at reducing carbon emissions may be directed at encouraging reducing reliance on paper-based mail, or reducing the regularity of deliveries (see, for example, Boldron et al., 2011), though it also suggested that the aggregation of activity by postal services reduces adverse environmental outcomes that would otherwise arise if multiple logistic providers operated to deliver last-mile services (see The Urban Institute, 2010).

5 In addition to these commonly accepted policy objectives, other socially beneficial outcomes associated with postal services include safety and security, which incorporates the role played by postal workers as a form of neighbourhood watch (The Urban Institute, 2010).
} 
priority letters) (see further below). ${ }^{6}$ In August 2019, Australia Post proposed to raise this basic price to $\$ 1.10$ in 2020 , which was accepted by the Australian Government on the advice of the Australian Competition and Consumer Commission and started on 1 January 2020 (for the change in the nominal and constant $\$$ price of basic postage in Australia from 2000 to 2020, see Figure 1).

Australia Post is also empowered to carry on, outside Australia, any business or activity relating to postal services (section 15, APC Act), as well as any business or activity inside or outside Australia that is incidental to such services, businesses or activities (section 16, APC Act). Among the range of activities that Australia Post undertakes are parcel delivery services, express post services, retail activities and the provision, as an agent, of a range of financial services, including billing transactions services (Australia Post, 2018, p. 1).

\begin{tabular}{|l|r|r|}
\hline & $\begin{array}{c}\text { Basic } \\
\text { stamp price }\end{array}$ & $\begin{array}{c}\text { Basic stamp } \\
\text { price (2018 cents) }\end{array}$ \\
\hline $\mathbf{2 0 0 0}$ & 45 & 72 \\
\hline $\mathbf{2 0 0 1}$ & 45 & 72 \\
\hline $\mathbf{2 0 0 2}$ & 45 & 67 \\
\hline $\mathbf{2 0 0 3}$ & 50 & 72 \\
\hline $\mathbf{2 0 0 4}$ & 50 & 71 \\
\hline $\mathbf{2 0 0 5}$ & 50 & 69 \\
\hline $\mathbf{2 0 0 6}$ & 50 & 66 \\
\hline $\mathbf{2 0 0 7}$ & 50 & 61 \\
\hline $\mathbf{2 0 0 8}$ & 50 & 62 \\
\hline $\mathbf{2 0 0 9}$ & 55 & 67 \\
\hline $\mathbf{2 0 1 0}$ & 60 & 71 \\
\hline $\mathbf{2 0 1 1}$ & 60 & 69 \\
\hline $\mathbf{2 0 1 2}$ & 60 & 67 \\
\hline $\mathbf{2 0 1 3}$ & 60 & 66 \\
\hline $\mathbf{2 0 1 4}$ & 70 & 75 \\
\hline $\mathbf{2 0 1 5}$ & 70 & 74 \\
\hline $\mathbf{2 0 1 6}$ & 100 & 105 \\
\hline $\mathbf{2 0 1 7}$ & 100 & 102 \\
\hline $\mathbf{2 0 1 8}$ & 100 & 100 \\
\hline $\mathbf{2 0 1 9}$ & 100 & 98 \\
\hline $\mathbf{2 0 2 0}$ & 110 & 108 \\
\hline
\end{tabular}

Figure 1. Basic stamp price in Australia, nominal and real 2000 to 2020 (cents and 2018 cents)

Source: Australia Post (2000-2019).

As with most postal services operating throughout the world, Australia Post is obliged to provide a range of CSOs. These are specified in the APC Act (section 27), which imposes the requirement on Australia Post to supply a letters service at a uniform rate within Australia for standard postal articles, and in so doing ensure that the service is reasonably accessible to all Australians and meets the social, industrial and commercial needs of the Australian community. The specific nature of these CSOs applicable to Australia Post are further specified in regulation, and insofar as they relate to delivery apply primarily to reserved services letters ${ }^{7}$ (for delivery service standards in place prior to measures introduced in response to the COVID-19 pandemic, see Table 1). ${ }^{8}$

\footnotetext{
6 See the Australian Postal Corporation (Performance Standards) Amendment (Speed of Mail Delivery) Regulation 2015 (Cth).

7 Reserved services letters are defined in the APC Act (see section 29: Services reserved to Australia Post etc.; see also section 3 (definition of 'letter' and 'standard postal article')).

8 As to amendments to regulations affecting delivery standards to deal with immediate issues arising from the COVID-19 pandemic, see the Australian Postal Corporation (Performance Standards) Amendment (2020 Measures No. 1) Regulations 2020 (Cth).
} 
Table 1. Performance standards applicable as at 7 February 2019

\begin{tabular}{|c|c|c|c|}
\hline \multicolumn{4}{|l|}{ Lodgement } \\
\hline \multicolumn{4}{|l|}{10,000 street posting boxes } \\
\hline \multicolumn{2}{|l|}{ Delivery timetables } & \multirow[t]{2}{*}{ Priority } & \multirow[t]{2}{*}{ Regular } \\
\hline $\begin{array}{l}\text { If the mail lodgement point } \\
\text { is ... }\end{array}$ & $\begin{array}{l}\text { and the delivery } \\
\text { address is ... }\end{array}$ & & \\
\hline \multicolumn{4}{|l|}{ Delivery within a state } \\
\hline in the capital city of a state & within that capital city & Next business day & 3 business days \\
\hline $\begin{array}{l}\text { in another city, or a town, in } \\
\text { a state }\end{array}$ & $\begin{array}{l}\text { within: } \\
\text { (a) that city or town; or } \\
\text { (b) an adjacent city or } \\
\text { town in that state } \\
\end{array}$ & Next business day & 3 business days \\
\hline in the capital city of a state & $\begin{array}{l}\text { in a place within that state } \\
\text { other than that capital city }\end{array}$ & 2 business days & 4 business days \\
\hline city, or a town, in a state & $\begin{array}{l}\text { in a place within that state } \\
\text { other than: } \\
\text { (a) that city or town; or } \\
\text { (b) an adjacent city or } \\
\text { town in that state }\end{array}$ & 2 business days & 4 business days \\
\hline $\begin{array}{l}\text { in a place in a state other than } \\
\text { a place mentioned }\end{array}$ & within that state & 2 business days & 4 business days \\
\hline \multicolumn{4}{|l|}{ Delivery between states } \\
\hline in the capital city of a state & $\begin{array}{l}\text { within the capital city } \\
\text { of another state }\end{array}$ & 2 business days & 5 business days \\
\hline outside the capital city of a state & $\begin{array}{l}\text { within the capital city } \\
\text { of another state }\end{array}$ & 3 business days & 6 business days \\
\hline outside the capital city of a state & $\begin{array}{l}\text { outside the capital city } \\
\text { of another state }\end{array}$ & 4 business days & 7 business days \\
\hline \multicolumn{4}{|l|}{ On time delivery } \\
\hline \multicolumn{4}{|l|}{$94.0 \%$ of reserved services letters } \\
\hline \multicolumn{4}{|l|}{ Access } \\
\hline \multicolumn{4}{|l|}{4,000 retail outlets } \\
\hline \multicolumn{4}{|c|}{2,500 retail outlets in rural and remote areas } \\
\hline \multicolumn{4}{|c|}{$\begin{array}{l}\text { Retail outlets located so that: } \\
\text { Metropolitan areas - at least } 90 \% \text { of residences are within } 2.5 \mathrm{~km} \text { of an outlet } \\
\text { Non-metropolitan areas - at least } 85 \% \text { of residences are within } 7.5 \mathrm{~km} \text { of an outlet }\end{array}$} \\
\hline \multicolumn{4}{|l|}{ Delivery frequency } \\
\hline \multicolumn{4}{|c|}{$98.0 \%$ of delivery points to receive five days a week } \\
\hline $99.7 \%$ of delivery points to rece & deliveries no less & we & \\
\hline
\end{tabular}

Source: The Australian Postal Corporation (Performance Standards) Regulations 2019. 
Further, the APC Act also imposes obligations on Australia Post with respect to international mail. Arrangements with respect to international mail are also governed by the Universal Postal Union (UPU) treaty arrangements, under which Australia Post is required to deliver inbound international mail on terms no less favourable than those applied to comparable items in the domestic service, increased by the time normally required for customs clearance (Universal Postal Convention Article 20(2): Universal Postal Union, 2017). Remuneration received by Australia Post in relation to all such deliveries are determined according to UPU rules. ${ }^{9}$

In providing its services, Australia Post is the subject of pricing oversight by the Australian Competition and Consumer Commission. Price notification provisions are contained in Part VIIA of the Competition and Consumer Act 2010 and apply to declared services. Where Australia Post proposes to increase prices of a declared service it must notify the Australian Competition and Consumer Commission. The commission must then consider the proposal in accordance with the Competition and Consumer Act 2010 and notify Australia Post whether it objects to the proposed price increase. The commission provides a recommendation to the Minister for Communications, and if the minister does not disapprove of the price increase Australia Post can go ahead with it. The Postal Services Legislation Amendment Act 2004 also introduced record-keeping rules to enable the commission to assess whether Australia Post has been unfairly competing by using revenue from its reserved services to cross-subsidise the services it provides in competition with other businesses, and to issue an annual report on this matter, although this report was discontinued from 2015/16 (Australian Competition and Consumer Commission, 2020).

\section{Changing nature of delivery of current USOs and the factors affecting this}

While the CSOs required to be met by Australia Post prior to the COVID-19 pandemic have been largely unchanged for the past four years, the nature of services that it is delivering continues to evolve rapidly, in large part due to the combination of technological change and with it the shifting reliance that the community is placing on traditional postal services relative to other services, such as telecommunications and parcel delivery.

\footnotetext{
9 Arrangements with respect to remuneration for international deliveries_otherwise known as the terminal dues system-were the subject of an Extraordinary Congress of the UPU in September 2019. The UPU resolved to reform the manner in which remuneration is set to allow member states to self-declare their rates from July 2020 (subject to some exceptions, for example, with respect to countries with low inbound letter-post volumes).
} 
The changing nature of Australia Post's service delivery profile is illustrated in Figure 2 and Table 2. Figure 2 shows the volume of postal articles carried by Australia Post between 2000 and 2019. As can be seen, there has been a steady decline since this volume peaked in 2008. Table 2 provides data on the overall revenue and expenses of the organisation as well as the relative share of revenue derived from mail, parcel/ express services and retail (and other) services since 2006 (columns 7-9). The decline in the volume of mail over time has contributed substantially to the decline in the profitability of the organisation since 2008 (see Figure 3).

\begin{tabular}{|l|r|}
\hline $\mathbf{2 0 0 0}$ & 5203.7 \\
\hline $\mathbf{2 0 0 1}$ & 5258.4 \\
\hline $\mathbf{2 0 0 2}$ & 5281.2 \\
\hline $\mathbf{2 0 0 3}$ & 5261.7 \\
\hline $\mathbf{2 0 0 4}$ & 5307.5 \\
\hline $\mathbf{2 0 0 5}$ & 5363.1 \\
\hline $\mathbf{2 0 0 6}$ & 5418.1 \\
\hline $\mathbf{2 0 0 7}$ & 5515.8 \\
\hline $\mathbf{2 0 0 8}$ & 5609.4 \\
\hline $\mathbf{2 0 0 9}$ & 5323.4 \\
\hline $\mathbf{2 0 1 0}$ & 5145.0 \\
\hline $\mathbf{2 0 1 1}$ & 5038.2 \\
\hline $\mathbf{2 0 1 2}$ & 4843.0 \\
\hline $\mathbf{2 0 1 3}$ & 4580.2 \\
\hline $\mathbf{2 0 1 4}$ & 4570.2 \\
\hline $\mathbf{2 0 1 5}$ & 4314.2 \\
\hline $\mathbf{2 0 1 6}$ & 4023.5 \\
\hline $\mathbf{2 0 1 7}$ & 3634.1 \\
\hline $\mathbf{2 0 1 8}$ & 3342.4 \\
\hline
\end{tabular}

Figure 2. Australia Post, articles posted in year ended $\mathbf{3 0}$ June (million) Source: Australia Post (2000-2019).

\begin{tabular}{|l|r|}
\hline $\mathbf{2 0 0 0}$ & 12.9 \\
\hline $\mathbf{2 0 0 1}$ & 12.6 \\
\hline $\mathbf{2 0 0 2}$ & 12.6 \\
\hline $\mathbf{2 0 0 3}$ & 13.7 \\
\hline $\mathbf{2 0 0 4}$ & 12.9 \\
\hline $\mathbf{2 0 0 5}$ & 11.2 \\
\hline $\mathbf{2 0 0 6}$ & 10.7 \\
\hline $\mathbf{2 0 0 7}$ & 10.2 \\
\hline $\mathbf{2 0 0 8}$ & 10.8 \\
\hline $\mathbf{2 0 0 9}$ & 8.9 \\
\hline $\mathbf{2 0 1 0}$ & 2.6 \\
\hline $\mathbf{2 0 1 1}$ & 8.0 \\
\hline $\mathbf{2 0 1 2}$ & 8.8 \\
\hline $\mathbf{2 0 1 3}$ & 9.2 \\
\hline $\mathbf{2 0 1 4}$ & 2.2 \\
\hline $\mathbf{2 0 1 5}$ & -6.9 \\
\hline $\mathbf{2 0 1 6}$ & 0.8 \\
\hline $\mathbf{2 0 1 7}$ & 2.3 \\
\hline $\mathbf{2 0 1 8}$ & 2.2 \\
\hline $\mathbf{2 0 1 9}$ & 0.7 \\
\hline
\end{tabular}

Figure 3. Australia Post rate of return: Profit before tax/total assets, year ended 30 June 2000 to 2019 (per cent)

Source: Australia Post (2000-2019). See Table 2 (this chapter), Column 4 divided by Column 5. 
Table 2. Australia Post: Key statistics, 2000 to 2019

\begin{tabular}{|c|c|c|c|c|c|c|c|c|}
\hline 1 & 2 & 3 & 4 & 5 & 6 & 7 & 8 & 9 \\
\hline $\begin{array}{l}\text { Year } \\
\text { ended } \\
30 \text { June }\end{array}$ & $\begin{array}{l}\text { Revenue } \\
\text { \$m }\end{array}$ & $\begin{array}{l}\text { Expenses } \\
\$ \mathrm{~m}\end{array}$ & $\begin{array}{c}\text { Profit } \\
\text { before } \\
\text { tax } \\
\$ \mathrm{~m} \\
\end{array}$ & $\begin{array}{l}\text { Total } \\
\text { assets } \\
\$ m\end{array}$ & $\begin{array}{c}\text { CsOs } \\
\$ \mathrm{~m}\end{array}$ & $\begin{array}{c}\text { Mail } \\
\text { revenue }^{*} \\
\$ \mathrm{~m}\end{array}$ & $\begin{array}{c}\text { Parcels } \\
\& \\
\text { express* } \\
\$ m\end{array}$ & $\begin{array}{c}\text { Retail, } \\
\text { agency } \\
\text { \& other* } \\
\$ \mathrm{~m}\end{array}$ \\
\hline 2000 & $3,785.8$ & 3,393.9 & 391.9 & $3,037.3$ & 81.7 & $\mathrm{n} / \mathrm{a}$ & $\mathrm{n} / \mathrm{a}$ & $\mathrm{n} / \mathrm{a}$ \\
\hline 2001 & $3,766.4$ & $3,364.3$ & 402.1 & $3,198.5$ & 86.3 & $\mathrm{n} / \mathrm{a}$ & $\mathrm{n} / \mathrm{a}$ & $\mathrm{n} / \mathrm{a}$ \\
\hline 2002 & $3,806.6$ & $3,399.4$ & 407.2 & $3,228.9$ & 87.9 & $\mathrm{n} / \mathrm{a}$ & $\mathrm{n} / \mathrm{a}$ & $\mathrm{n} / \mathrm{a}$ \\
\hline 2003 & $3,971.9$ & $3,509.9$ & 462.0 & $3,364.7$ & 90.3 & $\mathrm{n} / \mathrm{a}$ & $\mathrm{n} / \mathrm{a}$ & $\mathrm{n} / \mathrm{a}$ \\
\hline 2004 & $4,161.1$ & $3,640.0$ & 521.1 & $4,054.1$ & 79.1 & $\mathrm{n} / \mathrm{a}$ & n/a & $\mathrm{n} / \mathrm{a}$ \\
\hline 2005 & $4,325.9$ & $3,856.1$ & 469.8 & $4,192.7$ & 81.0 & $\mathrm{n} / \mathrm{a}$ & $n / a$ & $\mathrm{n} / \mathrm{a}$ \\
\hline 2006 & $4,530.1$ & $4,014.5$ & 515.6 & $4,808.4$ & 87.8 & $2,634.8$ & $1,095.8$ & 670.6 \\
\hline 2007 & $4,711.1$ & $4,367.0$ & 561.7 & $5,490.0$ & 97.3 & $2,679.0$ & 1,198.9 & 681.0 \\
\hline 2008 & $4,959.2$ & $4,367.0$ & 592.2 & $5,477.0$ & 104.3 & $2,731.2$ & $1,315.1$ & 713.4 \\
\hline 2009 & $4,974.5$ & $4,604.4$ & 380.9 & $4,270.2$ & 113.8 & $2,750.6$ & $1,348.5$ & 736.2 \\
\hline 2010 & $4,856.2$ & $4,767.6$ & 103.0 & $3,915.2$ & 145.7 & $2,658.1$ & $1,361.7$ & 712.0 \\
\hline 2011 & $4,986.5$ & $4,674.3$ & 332.0 & $4,135.1$ & 144.7 & $2,728.1$ & $1,434.0$ & 708.5 \\
\hline 2012 & $5,126.2$ & $4,776.3$ & 366.7 & $4,175.8$ & 165.2 & 2,312.1 & $1,822.6$ & 1,342.6 \\
\hline 2013 & $5,893.2$ & $5,490.3$ & 402.8 & $4,401.5$ & 177.5 & $2,207.8$ & $2,658.4$ & $1,370.0$ \\
\hline 2014 & $6,383.3$ & $6,280.3$ & 103.0 & $4,651.2$ & 205.8 & $2,110.4$ & $3,094.2$ & $1,465.7$ \\
\hline 2015 & $6,373.8$ & $6,725.9$ & -352.1 & $5,094.4$ & 211.6 & $2,074.9$ & $3,207.0$ & $1,491.1$ \\
\hline 2016 & $6,562.2$ & $6,521.2$ & 41.0 & $5,043.2$ & 183.6 & $\mathrm{n} / \mathrm{a}$ & $n / a$ & $\mathrm{n} / \mathrm{a}$ \\
\hline 2017 & $6,807.2$ & $6,681.1$ & 126.1 & $5,537.3$ & 389.9 & $2,991.8$ & $2,694.3$ & 962.4 \\
\hline 2018 & $6,877.0$ & $6,751.3$ & 125.7 & $5,590.9$ & 403.5 & $2,903.6$ & $2,913.9$ & 966.9 \\
\hline 2019 & $6,989.8$ & $6,950.3$ & 41.1 & $5,536.6$ & 392.2 & $2,216.3$ & $3,808.8$ & 968.7 \\
\hline
\end{tabular}

Note: ${ }^{\star}$ Changes in the divisions of Australia Post make some years not compatible.

Source: Australia Post 2000-2019.

The changing nature of Australia Post's business can be seen from the figures in columns 7, 8 and 9 of Table 2. Since 2006 the proportion of Australia Post's revenue derived from mail has fallen from 58 per cent in 2006 to 40 per cent in 2019 . Over the same period, parcels and express delivery has risen from 24 to 42 per cent, while retail, agency and others has been fairly stable at around 14 to 15 per cent. The changing nature of Australia Post's revenue reflects both the impact of technology change on its traditional mail business, and also the extent to which it is increasingly reliant on revenue from those parts of its business which are subject to competition (i.e. the parcel business).

In considering the nature of Australia Post's parcel delivery business, it is necessary to recognise that the geographical reach of Australia Post is such that, in a range of instances, its competitors themselves rely on Australia Post's delivery services to meet their own customers' needs. As this article examines further below, this gives 
weight to the question of whether, if at all, the extent to which parcel deliveries are reliant on the ubiquity of Australia Post's coverage provides an ongoing and evolving justification for the maintenance of some form of CSOs in the regulatory structure of Australia's postal services.

The changing shape of Australia Post's business, however, also raises broader questions as to the ongoing efficacy of the CSOs that it is required to deliver. As noted above, there has been a significant decline in the traditional mail business, which appears to be continuing and indeed accelerating. In large part, this is a consequence of technological change, which has meant the provision of communications traditionally met by mail is increasingly being delivered through alternative means - that is, via the internet and related telecommunications-based applications - that are both more efficient and convenient. At the same time, as Table 2 illustrates (column 6), the costs associated with Australia Post's CSOs are rising significantly, while profitability has been declining (see column 4, Table 2, and Figure 3). Hence, as the benefits associated with traditional CSOs are reducing, the capacity of Australia Post to deliver them is falling. To the extent that Australia Post is required to fund the delivery of these CSOs directly, this in turn has the potential to reduce Australia Post's competitiveness in product markets for which it is required to compete-an effect not sufficiently offset by the revenue and/or profit obtained from the delivery of services reserved solely for provision by Australia Post under legislation.

It is possible that this situation could be alleviated if reform to Australia Post's business processes are able to achieve efficiencies that lower the cost of delivering services, both generally and specifically with respect to CSOs. In this regard, the changing landscape has prompted significant reform in how Australia Post undertakes its operations, focusing both on operational improvements in the delivery of traditional services as well as facilitating the expansion and productivity of parcel delivery activities. Strategies adopted with respect to enhancing the profitability of its letters service, for example, have included:

- process optimisation, including enterprise agreements that reform labour practices and reduce staffing levels

- process automation and technological innovation, such as new sorting machines at major mail centres to streamline processing

- facilitating the modification of the prescribed performance standards required to be met $^{10}$

- better utilisation of its delivery network, in particular by integrating letters and parcel delivery through Australia Post's eCommerce Delivery Team, ${ }^{11}$ and the introduction of more efficient distribution channels (e.g. parcel lockers).

10 This is manifested in the introduction of two-tier letter pricing (with less onerous delivery performance standards for regular mail). For further details and discussion of these changes see Australian Government Department of Communications (2015).

11 See Australian National Audit Office (2017), Chapter 2. 
Such reforms to Australia Post's operations reflect a more general trend worldwide, which has seen a variety of operational changes as postal organisations have sought to address declining demand and digital disruption. While it is beyond the scope of this article to address such reform efforts in detail, similar to Australia Post this has seen both increases in prices and greater pricing flexibility, changes in service delivery requirements and a variety of operational enhancements, including the utilisation of technology, increased centralisation in some instances (e.g. PostNL; Post Danmark), plant consolidation (e.g. Post Canada, New Zealand Post) and changes in delivery models and delivery channels. ${ }^{12}$ While such changes have been directed at improving financial sustainability, the ongoing shifts in demand create ongoing and likely growing pressure on the capacity of postal organisations to deliver their more traditional services, and relatedly fulfil their CSOs.

As such, the changes being experienced in the postal sector create the need to reconsider the nature and scope of the CSOs that apply to postal services-a situation that has received recognition more broadly than just Australia. As Falch and Henten (2018) note, for example, it has been suggested that the EU should initiate a discussion on whether USOs are still meaningful in postal services alone, or rather that consideration be given to a comprehensive redefinition of the USO concept, towards a more general 'right to communicate'. In the case of Australia, the Australian National Audit Office (2017) similarly suggested that:

[g]iven the changing composition and narrowing of the user base for regulated letter delivery services, it may be that there are more effective ways of providing support to meet public policy objectives that do not involve using a broad-based CSO. A full examination of the costs and benefits of delivering the CSO would include a detailed consideration of the beneficiaries of the CSOs, the value of those benefits over time, and alternative options for delivering those benefits. This analysis would better inform decisions on whether the CSO remains relevant and fit for purpose, and if not, whether there are alternative policy approaches to adopt. (p. 64)

It is in light of these forces that this paper now considers the potential future nature of CSOs that may relevantly be provided by Australia Post, having particular regard to both the range of technological changes impacting on communications and the shifting community demands for services currently and potentially provided by Australia Post. ${ }^{13}$

12 As to examples of similar reforms in other national postal organisations, see for example The Boston Consulting Group (2014) and Copenhagen Economics (2018).

13 According to Jaag and Trinckner (2011), such re-evaluation needs to have regard to five core principles: a focus on outputs (such as delivery times) rather than inputs (such as number of postal outlets), technological neutrality, product neutrality, necessity and viability. In a similar vein, the United States Postal Services (USPS) Office of Inspector General (2014) argued in favour of ensuring clarity of policy goals; recognition that the USO should define the floor and the market ceiling of services to be provided; that USOs should be flexible enough to enable adaptation to changing market conditions over multiple years; that they should be defined in terms of the service received, not how the service is provided; that they need to be financially sustainable while reasonably priced; and finally that any USO requirements should be transparent and measurable. 


\section{Considering reform to the CSOs delivered by Australia Post}

In considering the potential nature of CSOs that should apply to Australia Post in the future, it is necessary to have regard to who the users, and hence the beneficiaries, of those CSOs might be, and in which capacity they are accessing those services. Historically, user groups intended to benefit from CSOs in the postal sector have been those living in rural/remote places, those with disabilities and reduced mobility, customers who are blind or visually impaired, and those on low income or who are elderly (Deloitte Access Economics, 2018; Industry Commission, 1997). It would be anticipated that these categories continue to represent those groups who should be the target of CSOs applicable to the postal sector.

In terms of the capacity in which such recipients fall, this categorisation may either relate to the type of user group a person falls within-for example, consumers as senders, consumers as receivers, small businesses—or to which postal services might be needed and for what purposes. In this context, for example, traditional mail may have a range of different purposes, including interaction with businesses, managing customer relationships, social interaction, social integration, meeting information needs, interaction between public institutions and citizens, and the delivery of goods. The degree to which changes associated with e-substitution have reduced, or will reduce, the need for CSOs that relate primarily to traditional mail services will then necessarily have regard to the extent to which substitution has occurred, or can be anticipated to occur, with respect to each of these different purposes for which mail is used.

In this regard, social media has made substantial inroads into mail used for social interaction, reducing the need for CSOs for that purpose; at the same time, transactions are increasingly moving towards email-based billing and online applications, including online payments systems. Similarly, digital marketing has manifested as a substitute for direct mail advertising materials, while physical publications such as newspapers and magazines are increasingly deliverable through digital media. Finally, reliance in Australia on traditional mail by government institutions appears also to have changed, albeit at a somewhat slower pace-with some aspects still requiring physical mail delivery (e.g. identification for election purposes), others less so. In this regard, Australia does not appear to have changed as rapidly as some other countries - for example, Denmark, which have sought to move quickly to e-government platforms (see Eggrickx et al., 2018). ${ }^{14}$

14 In Denmark, the drive for e-government encompassed the rollout of mandated digital mailboxes and a requirement for all interactions to be done, or capable to be done, electronically within specified timeframes (i.e. since 2014) (see Falch \& Henten, 2018). 
As Figure 2 suggests, digital alternatives have already substantively reduced the volume of traditional mail. Having regard to the CSOs that are delivered through the medium of such mail products, the extent of this e-substitution has the twofold effect of lessening the benefits that stem from the provision of traditional CSOs through the postal service, while at the same time raising the effective unit costs associated them. As such, it creates pressure to either constrain the extent of those CSOs, or to find alternative mechanisms or more efficient means by which they might be provided.

This effect has been noted by the United States Postal Service (USPS), who, in considering how USOs may be reformed to meet changing needs, has reflected that USOs might need to be focused to narrower subsets of the population-referring in particular to those who do not have access to broadband and those who are unwilling to trust or unable to use digital alternatives (for example, a proportion of more elderly customers) (USPS Office of the Inspector General, 2014). On this aspect of access to digital alternatives, it is noted that the rollout of the National Broadband Network (NBN) in Australia can be anticipated to accelerate the pace of change, and hence the decline of traditional mail services. In so doing, it also diminishes the need for traditional CSOs delivered through the postal system, albeit subject to the differences in quality and limitations in reach that may exist under the NBN (Given, 2008).

While digitalisation is reducing the demand for traditional mail services, and hence the benefits associated with traditional CSOs, it is also associated with changing economic behaviours that create a burgeoning need for related servicesin particular, parcel delivery services associated with online retailing. As Table 2 illustrates, the growth in online retail has already had a substantive impact on the nature and structure of Australia Post's business, with parcel revenues almost tripling over the past dozen years (see column 8).

This is turn gives rise to a question in relation to this growth in parcel revenues as to whether the underlying demand for such services is one that should be the subject to some form of formal USO, or indeed the predominant policy outcome that postal USOs aim to address. Such an approach has been supported by Zaiac (2019) in considering how USOs that apply to the USPS should be formalised, and similarly by Hearn (2016) in the context of a potential reconsideration of the European Union's Postal Directive. In part, this question depends upon the extent to which the changing nature of retailing is likely to impact disproportionately across the community, and in particular how it may impact on rural and remote areas. That online retail will impact on traditional retail activities is already well recognised (Cushman \& Wakefield, 2013), and the change is anticipated to be ongoing. Overall, online retail is estimated to be around 10 per cent of all retail in Australia (as of 2019), with growth rates expected to be strong over the next five years. 
Compared to other countries this is a relatively high level, although not as high as the United States, the world's most developed online market, where 13 per cent of all retail was online (Australia Post 2018, 2019).

The effects of ecommerce on retail behaviour in different regions, however, has been less widely canvassed. Within Australia, growth in ecommerce has been strongest in the main regional centres and in the outer suburbs of Australia's capital cities (Australia Post 2018, 2019). However, as Australia Post (2019) also notes:

households in remote and very remote Australia that do shop online are doing so more frequently. The rate of purchase is 1.2 times the national average. It is likely households in remote regions depend on online shopping to access a wider range of products, given the distance to their nearest shopping centre. (p. 23)

Differences in the growth in ecommerce by region are further illustrated in Table 3, which details year-on-year online shopping growth by region (overall and by product category). This table shows that whereas remote and very remote Australia have lower than average growth rates in all categories, their relative growth is higher with respect to the 'Variety stores' and 'Homewares \& appliances' categories. This suggests a relatively greater focus on household necessities in remote and very remote regions, as compared more discretionary products such as 'Fashion' and 'Hobbies $\&$ recreational goods'.

Table 3. Year-on-year online shopping growth $(\%, 2018)$

\begin{tabular}{|l|r|r|r|r|r|r|}
\hline & \multicolumn{1}{|c|}{ All } & \multicolumn{1}{|c|}{$\begin{array}{c}\text { Major } \\
\text { cities of } \\
\text { Australia }\end{array}$} & $\begin{array}{c}\text { Inner } \\
\text { regional } \\
\text { Australia }\end{array}$ & $\begin{array}{c}\text { Outer } \\
\text { regional } \\
\text { Australia }\end{array}$ & $\begin{array}{c}\text { Remote } \\
\text { Australia }\end{array}$ & $\begin{array}{c}\text { Very } \\
\text { remote } \\
\text { Australia }\end{array}$ \\
\hline Total & 20.2 & 20 & 21.4 & 19.7 & 16.3 & 15.1 \\
\hline Fashion & 20.4 & 20.3 & 22.3 & 19 & 13.3 & 10.5 \\
\hline Variety stores & 21.5 & 20.7 & 23.3 & 23.6 & 21.3 & 18.6 \\
\hline Health \& beauty & 29.4 & 31.1 & 27.6 & 22.4 & 20.5 & 11 \\
\hline Homewares \& appliances & 11.7 & 12.8 & 10.4 & 8.5 & 7.3 & 8.8 \\
\hline Hobbies \& recreational goods & 8.5 & 7.8 & 10.8 & 10 & 6.7 & 2.5 \\
\hline
\end{tabular}

Source: Australia Post (2018).

The differences in growth rates by region illustrate the multiplicity of forces driving changes in consumer behaviour. The strong growth of online retail in major regional centres and the outer suburbs of the capital cities appears to be reflective both of the demographic structures of those communities (e.g. higher proportions of families, lower-middle income households, etc.), as well as the ready access to, familiarity with and comfort in engagement with ecommerce opportunities. This compares to the factors influencing growth in remote and very remote areas, which are more likely the product of lesser alterative retail options as well as the beneficial cost structures associated with current pricing and delivery arrangements in the postal sector. 
More broadly, however, it should be recognised that it appears it is access to a wider range of sellers, with resultant benefits including lower product pricing and a greater diversity of goods available for purchase, rather than postal pricing differences that appears to be driving growth in ecommerce generally. This is reflected in the geographical spread of ecommerce suppliers. In the case of Australia, for instance, China (41 per cent), the United States (21 per cent) and the United Kingdom (14 per cent) make up the bulk of the sources of online retail purchases in Australia (International Post Corporation, 2019).

In considering the extent to which the changing nature of retail may warrant the formal recognition of CSOs more heavily related to parcel deliveries, regard should also be given to the extent to which third-party logistic service providers rely upon the postal sector for last mile delivery. The greater the role of the postal service, the more likely a CSO may be appropriate.

In the United States, for example, the taskforce examining the USPS (United States Government Taskforce on the United States Postal System, 2018, p. 13) found that while the postal service had only a 17 per cent share of competitive end-to-end package delivery revenue in the 2016 financial year (compared to the United Parcel Service's 40 per cent market share and Federal Express's 30 per cent market share), the USPS played a greater role in the delivery of lightweight packages to households. Further, the USPS handled much of the 'last mile' delivery for the other carriers.

In Australia, while the extent to which third-party carriers rely on Australia Post is opaque, there are commercial arrangements in place between Australia Post and third-party carriers for parcel delivery services, particularly in regions outside metropolitan boundaries that are not covered directly by the third-party carrier delivery networks. This suggests that economic forces militate against multiple delivery services operating across the more remote parts of Australia, or alternatively that Australia Post is delivering parcels to remote regions below cost, which makes competition prohibitive and constitutes a form of informal CSO. If that is the case, then cross-subsidising parcels is unsustainable because although parcel work is expanding there is no monopoly rent to pay for the cross-subsidy. If the crosssubsidy is substantial then it is being paid for by what is left of the reserved letter service monopoly rent, or what would once have been the organisation's profit. In such circumstances, if the money from the reserved letter services is declining and continues to do so, and if parcel delivery to remote areas continues to grow, something must give. It is unclear that any amount of organisational improvement is going to fix such a problem. If not, then ultimately there would be only two alternatives: higher country delivery prices or instituting a formal CSO arrangement.

While the changing nature of Australia Post's mail and parcel delivery activities will likely play a key role in decisions regarding the shape and structure of ongoing CSOs, Australia Post is engaged in a range of other activities that may also be 
relevant in consideration of future CSOs. One such potential area of activity is in the provision of financial services. As noted above, provision of financial services can form a substantial part of the business activities run by postal services, as is the case in New Zealand, Italy and Japan. Attributes contributing to this role include the geographical spread of post offices, and the implicit protection of being a government-owned institution.

Historically, Australia Post has delved into the provision of financial services, and the nature of such provision in the context of CSOs has also been considered. During the 1990s and 2000s, for example, one factor adding pressure on ensuring the ubiquity of Australia Post services was to ensure the provision of cash and access to financial services to rural and remote communities (see, for example, Parliamentary Joint Committee on Corporations and Financial Services, 2004).

To this end, Australia Post has entered into agency arrangements with a range of financial institutions and has played a front-facing role in facilitating transaction services, in particular bill payment, for both businesses and government. Unlike other postal services around the world (see Falch \& Henten, 2018), however, Australia Post has not chosen to enter into the financial services as a direct provider. As it does not currently undertake such a role, and with the development of internetbased banking and a plethora of online payment systems, the pressure for CSOs associated with financial services would appear to have abated considerably, and will likely continue dropping.

Another potential area of activity that supports various aspects of Australia Post's current CSOs, and which may constitute CSOs in their own right, is a range of government services to be delivered through its outlets. Currently, these relate to both national and state/territory services, in particular ID and document services (such as passport, tax file number and ID applications, as well as police check applications).

In considering whether the current and future provision of such government services may be an appropriate basis for CSOs, a key question is whether there are economies of scope that would underpin the delivery of such services through a joint network, of which the Australia Post retail network may provide the foundation. Cooperation with the state and territory governments would increase the scope for delivery of these types of services and could include such things as motor vehicle registration, licence renewals and so on. It is noted, for example, that some states and territories maintain a network of physical agencies at which a range of government services are provided (e.g. Access Canberra, Service NSW, Service SA, Service Tasmania). ${ }^{15}$ However, a likely consequence of expanding Australia Post's role in the delivery of

15 In 2019 Western Australia announced also that ServiceWA would pilot a 'one-stop shop' in Bunbury to make it easier for the community to access a range of government services. 
government services — and developing and applying related CSOs_—would be to add pressure for its retention as a government-owned entity. Such status is anticipated to be required both to maintain customer trust ${ }^{16}$ and also to support willingness to participate across the various levels of government.

Related to the role that Australia Post's physical network provides as a basis for re-examining the scope of its role as a provider of CSOs, consideration may also be given to the extent to which government services might be best delivered through alternative mechanisms provided by Australia Post. One possible example of this is the notion of a digital mailbox, which has been introduced in a range of countries as the official location for the receipt of government correspondence. ${ }^{17}$ While Australia Post directed some effort towards introducing a digital mailbox system in Australia, its establishment does not appear to have been particular effective.

\section{Conclusion}

Historically, the main drivers of mail volumes and reliance on postal services were economic, income and population growth (ERGP, 2016a, 2016b; Hooper et al., 2010). This is no longer the case, with technology and evolving consumer and business behaviours rapidly changing the nature of the market and community in which postal services operate-changes that are likely to have accelerated in response to the COVID-19 pandemic. With these changes comes the need to consider the case for, and potentially a recasting in the nature and manner of, provision of the CSOs which postal services have traditionally provided.

In the case of developing countries, where CSOs have historically not been met to any great degree, this had led to questions as to whether such obligations should not be sought to be imposed - the core argument being that the resources required to meet the needs being satisfied by delivering such USOs could be better utilised on other, more necessary services such as health and education (Kenny, 2005). In contrast, in developed countries such as Australia, the questions are more around the continued relevance of traditional USOs, and the potential changes which may be appropriate.

In considering the future of USOs in the United States, the United States Government's Task Force on the United States Postal System (2018) noted that, going forward:

\footnotetext{
16 As to Australian's perceptions of Australia Post, including levels of trust in its brand, and the place of Australia Post as part of the national identity, see Deloitte Access Economics (2018).

17 This process has not been without difficulties, with some countries having a low take-up of its use. In Singapore, for instance, the service was abolished in 2017 after operating for five years (The Straits Times, 6 April 2017).
} 
the USO must distinguish between the types of mail and packages for which a strong social or macroeconomic rationale arises for government protection in the form of price caps and mandated delivery standards ('essential services') versus those types of mail and packages that are commercial in nature, and therefore would not have a basis for government protection.

This article has focused on the CSOs delivered by Australia Post. In Australia, the extent to which physical delivery is required through a postal system is changing rapidly. On the one hand, the relative reliance that the community places on communication in physical form (e.g. letters) is diminishing; on the other, the extent to which the community is becoming reliant on delivery networks for retail products is growing substantially (and, in turn, adversely impacting on the viability of other, more traditional retail outlets).

Together these changes indicate that a reconsideration is required of the nature of the CSOs that should apply to the postal service. In particular, greater consideration should be given to assessing the extent to which market forces alone will enable parcel delivery services to exist at an acceptable standard across the community, or whether intervention is required to ensure parts of the community-particularly those living in rural and remote areas-continue to receive at least the basic level of services considered to be appropriate for all. In the current circumstances in Australia the delivery of parcels to remote regions appears to be cross-subsidised, as evidenced by the lack of service delivery in some places by non-Australia Post carriers. These carriers use the Australia Post service, both because Australia Post likely delivers below cost, and/or below the cost they could otherwise deliver themselves. Internally financing any cross-subsidisation into the future will be problematic, given that the monopoly profits of the Australian Post reserved letter service is being eroded by electronic communication technology. In addition, in itself parcel delivery has no monopoly reserved service component with which to finance this cross-subsidy. At present, cross-subsidisation would in effect be funded by lower profitability for Australia Post, which is currently not making a commercial rate of return. This is unlikely to be a permanent solution, and at some point full cross recovery will be required of parcel delivery to remote regions (i.e. higher prices) or funding either from the government budget or some introduction of a parcel reserved service.

In a similar vein, it would appear, given the physical nature of the postal service network that Australia Post operates, that scope also exists for this to be used to ensure a required level of service provision in relation to government services. In this regard, there appears to be potential for an expanded service delivery role with respect to government services provided at both the federal and state/territory levels. Such an expansion of Australia Post's role as government service deliverer would, however, likely be associated with consequent pressure for its ongoing retention as a government-owned entity. 


\section{References}

Abbott, M. (2000). An economic evaluation of the Australian Postal Corporation Act 1989. Economic Papers, 19(3), 1-15.

Abbott, M. (2019). The long-term performance of a utility: The case of the Australian Post Office. Competition and Regulation in Network Industries, 19(3-4), 1-22. doi.org/ $10.1177 / 1783591719829043$.

Ambrosini, X., Boldron, F. \& Roy, B. (2006). Universal service obligations in the postal sector: Economic learnings from cross-country comparisons. In M. Crew and P. Kleindorfer (Eds), Progress toward liberalization of the postal and delivery sector (pp. 2337). Springer. doi.org/10.1007/978-0-387-29744-6_2.

Australia Post. (2000-2019). Australia Post annual report. [See individual reports for each financial year.] Australia Post.

Australia Post. (2018). Inside Australian online shopping: 2018 eCommerce industry report. Australia Post.

Australia Post. (2019). Inside Australian online shopping: 2019 eCommerce industry report. Australia Post.

Australian Competition and Consumer Commission. (2014). Tests for assessing cross-subsidy. Australian Competition and Consumer Commission.

Australian Competition and Consumer Commission. (2020). ACCC role in postal services. www.accc.gov.au/regulated-infrastructure/postal-services/accc-role-in-postal-services.

Australian Government Department of Communications. (2014). The Australian postal market (Policy Background Paper No. 4). Commonwealth of Australia.

Australian Government Department of Communications. (2015). Regulation impact statement for proposed reform to postal regulation. Commonwealth of Australia.

Australian National Audit Office. (2017). Australia Post's efficiency in delivering reserved letter services (ANAO Report No. 11, 2017-18 Performance Audit). Australian National Audit Office.

Boldron, F., Borsenberger, C., Cremer, H., de Donder, P., Joram, D. \& Roy, B. (2011). Environmental cost and universal service obligations in the postal sector. Review of Network Economics, 10(3), 1-18. doi.org/10.2202/1446-9022.1226.

Boldron, F., Cremer, H., de Donder, P., Joram, D. \& Roy, B. (2007). Social costs and benefits of the universal service obligation in the postal market (No. 456, IDEI Working Papers). Institut d'Économie Industrielle. 
Boldron, F., Cremer, H., de Donder, P., Joram, D. and Roy, B. (2009). Network externalities and the USO: A two-sided market approach. In M.A. Crew and P.R. Kleindorfer (Eds), Progress in the competitive agenda in the postal and delivery sector (pp. 184-195). Edward Elgar Publishing. doi.org/10.4337/9781848447288.00018.

Calzada, J. (2009). Universal service obligations in the postal sector: The relationship between quality and coverage. Information Economics, 21(1), 10-20. doi.org/10.1016/ j.infoecopol.2008.07.002.

Chone, P., Flochel, L. \& Perrot, A. (2000). Universal service obligations and competition. Information Economics and Policy, 12(3), 249-259. doi.org/10.1016/s0167-6245(00) 00014-7.

Copenhagen Economics. (2018). Main developments in the postal sector (2013-2016) (Study for the European Commission, Directorate-General for Internal Market, Industry, Entrepreneurship and SMEs).

Cremer, H. Gasmi, F., Grimaud, A. \& Laffont, J.-J. (1998). The economics of universal service: Theory. The Economic Development Institute of the World Bank.

Cremer, H., Gasmi, F., Grimaud, A. \& Laffont, J. (2001). Universal service: An economic perspective. Annals of Public and Cooperative Economics, 72(1), 5-43.

Cuomo, M., Nardone, T., Rovero, A. \& Scarfiglieri, G. (2013). Electronic substitution and USO scope definition. In M.A. Crew and P.R. Kleindorfer (Eds), Reforming the postal sector in the face of electronic competition (pp. 179-193). Edward Elgar Publishing. doi.org/ $10.4337 / 9780857935809.00018$.

Cushman \& Wakefield (2013). Global perspective on retail: Online shopping. Cushman \& Wakefield.

Deloitte Access Economics (2018). Economic and social value of Australia Post. Deloitte Access Economics.

Eggrickx, B., Klargaard, O., Lefort, M. \& Regnard, P. (2018). E-government: A curse or an opportunity for posts. In P. Parcu, T. Brennan \& V. Glass (Eds), New business and regulatory strategies in the postal sector (pp. 234-249). Springer. doi.org/10.1007/978-3030-02937-1_18.

European Regulators Group for Postal Services. (2016a). Report on the outcome of the ERGP public consultation on the evolution of the universal service obligation (ERGP PL (15) 14). European Regulators Group for Postal Services .

European Regulators Group for Postal Services. (2016b). Report on universal services in light of changing postal end users' needs (ERGP (16) 36). European Regulators Group for Postal Services.

Falch, M. \& Henten, A. (2018). Universal service in a digital world: The demise of postal services. Nordic and Baltic Journal of Information and Communications Technologies, 28(1), 207-222. 
Faulhaber, G.R. (1975). Cross-subsidization: Pricing in public enterprises. American Economic Review, 65(5), 966-977.

Gautier, A. \& Poudou, J.-C. (2014). Reforming the postal universal service. Review of Network Economics, 13(4), 453-477. doi.org/10.1515/rne-2015-0001.

Geddes, R.R. (1994). Agency costs and governance in the United States Postal Service. In J. Gregory Sidak (Ed.), Governing the postal service (pp. 114-140). The AEI Press.

Given, J. (2008). The eclipse of the universal service obligation: Taking broadband to Australians. Info, 10(5/6), 92-106. doi.org/10.1108/14636690810904742.

Hearn, J. (2016) Implications of recent developments in e-commerce for universal service providers and the USO. In M.A. Crew and T.J. Brennan (Eds), The future of the postal sector in a digital world. Springer. doi.org/10.1007/978-3-319-24454-9_4.

Hooper, R. (2010). Saving the Royal Mail's universal postal service in the digital age: An update of the 2008 Independent Review of the Postal Service Sector (Presented to Parliament by the Secretary of State for Business, Innovation and Skills By Command of Her Majesty, Cm 7937).

Industry Commission. (1997). Community services obligations: Policies and practices of Australian Governments [information paper]. Industry Commission.

International Post Corporation. (2019). Cross border e-commerce shopper survey 2018. International Post Corporation.

Jaag, C. (2013). Intellectual property rights and the future of universal service obligations in communications (No. 40, Working Papers). Swiss Economics.

Jaag, C. \& Trinckner, U. (2011). The future of the USO: Economic rationale for universal services and implications for a future-oriented USO (No. 26, Working Papers) Swiss Economics.

Kenny, C. (2005). Reforming the posts: Abandoning the monopoly-supported postal universal service obligation in developing countries (World Bank Policy Research Working Paper 3627). World Bank. doi.org/10.1596/1813-9450-3627.

Meagli, M., Jaag, C., Koller, M. \& Trinkner, U. (2011). Postal markets and electronic substitution: Implications for regulatory practices and institutions in Europe. In M.R. Crew and P.R. Kleindorfer (Eds), Reinventing the postal sector in an electronic age (pp. 109-122). Edward Elgar Publishing. doi.org/10.4337/9781849805964.00013.

Niskanen, W. (1975). Bureaucrats and politicians. Journal of Law and Economics, 18, 617-643. doi.org/10.1086/466829.

Parliamentary Joint Committee on Corporations and Financial Services. (2004). Money matters in the bush: Inquiry into the level of banking and financial services in rural, regional and remote areas of Australia. Commonwealth of Australia.

Sappington, D.E.M. \& Sidak, J.G. (2003). Incentives for anticompetitive behavior by public enterprises. Review of Industrial Organization, 22, 183-206. 
Sidak, J.G. (2015). Maximizing the U.S. Postal Service's profits from competitive products. Journal of Competition Law \& Economics, 11(3), 617-669. doi.org/10.1093/joclec/nhv026.

The Boston Consulting Group. (2014). Australian and international postal services overview: Background report. Boston Consulting Group.

The Urban Institute. (2010). A framework for considering the social value of postal services (Final Report, prepared for the Postal Regulatory Commission). The Urban Institute.

Tobin, J. (1970). On limiting the domain of inequality. Journal of Law and Economics, 13(2), 263-277.

United States Government Taskforce on the United States Postal System. (2018). United States Postal Service: A sustainable path forward: Report from the Task Force on the United States Postal System. Taskforce on the United States Postal System.

United States Postal Services (Office of Inspector General). (2014). Guiding principles for a new universal service obligation (RARC Report, RARC-WP-15-001). United States Postal Services.

Universal Postal Union. (2017). Decisions of the 2016 Istanbul Congress: Final texts of the acts signed at Istanbul and of the decisions other than those amending the acts. International Bureau of the Universal Postal Union.

Willig, R. (1979). The theory of network access pricing. In H. Trebing (Ed.), Issues in public utility regulation. Michigan State University.

Zaiac, N. (2019). Formalizing the USPS universal service obligation (R Street Policy Study No. 177). R Street Institute. 
This text is taken from Agenda, Volume 27 - Number 1, 2020, edited by William Coleman, published 2020 by ANU Press, The Australian National University, Canberra, Australia.

doi.org/10.22459/AG.27.01.2020.02 